\title{
Europska politika integracije migranata: od standardiziranja mjera za zemlje Europske unije prema integracijskom servisu utemeljenom na društvenoznanstvenim spoznajama
}

\author{
Saša BOŽıć \\ Odjel za sociologiju Sveučilišta u Zadru, Hrvatska \\ sbozic@unizd.hr \\ Simona KUTI \\ Institut za migracije i narodnosti, Zagreb, Hrvatska \\ simona.kuti@imin.hr
}

\begin{abstract}
Članak prikazuje i analizira temeljne dokumente Europske unije o integraciji migranata te na temelju postojećih društvenoznanstvenih rasprava, posebice novijih socioloških koncepata i istraživanja društvenih procesa koji uključuju migrante, nastoji ponuditi relevantniji okvir za angažman institucija Europske unije u tim procesima. Autori analiziraju dosadašnje kritike europske integracijske politike nastale u okvirima društvenih znanosti te upućuju na relevantnost suvremenih socioloških koncepata i istraživanja procesa integracije migranata za formuliranje pragmatičnog pristupa Europske unije migrantskoj integraciji. »Nadraznolikost« (»superdiversity«), segmentirana integracija i jačanje transnacionalnih veza migranata pokazuju da je pretpostavljeno holističko integriranje migrantskih populacija u koliziji s društvenom stvarnosti višedimenzionalne prilagodbe migrantskih i nemigrantskih populacija etničkim, demografskim, ekonomskim, kulturnim i drugim promjenama u urbanom kontekstu suvremenih europskih društava. Autori zaključuju da umjesto standardiziranja mjera integracije za nacije-države na nadnacionalnom nivou, Europska unija valja ponuditi bitno pragmatičniji pristup integraciji migranata utemeljen na relevantnim spoznajama društvenih znanosti, ali i konkretnim »terenskim iskustvima« istraživača, praktičara, migrantskih organizacija i lokalnih vlasti.
\end{abstract}

Ključne riječi: integracija migranata, Europska unija, javne politike, migracije, migrantske politike, »nadraznolikost« 


\section{Uvod}

U javnom diskursu većine zemalja Europske unije (EU) dominira ideja da EU nije dobro reagirala na povećanje broja izbjeglica i neregularnih migranata tijekom i nakon 2015. godine. Uz uobičajene kritike o potpuno različitim interesima zemalja članica koje ne koordiniraju mjere za reguliranje toka, smještaja i integracije migranata, često se naglašavaju neadekvatne migracijske i migrantske politike, posebice mjere integracije migranata. Međutim, opravdane kritike o načinu tretiranja uzroka i posljedica izbjegličkih i drugih migracijskih tokova tijekom i nakon 2015. uglavnom ne prate razvoj promišljanja i pokušaje reguliranja migrantske problematike unutar institucija EU-a. Različitim institucijama i tijelima EU-a može se prigovoriti da sporo i neadekvatno reagiraju na važne probleme europskih društava, ali im se ne može predbacivati da je pitanje reguliranja migracija, posebice integracije migranata, zanemareno. Prvi europski dokument o integraciji migranata usvojen je još 1974., a od 1999. godine europske institucije redovito razmatraju i razvijaju migracijske i integracijske politike.

Temeljni problem bavljenja migracijskom problematikom unutar institucija EU-a jest plakativno prikazivanje procesa integracije migranata uz obvezno »izlistavanje« mjera i preporuka koje se temelje s jedne strane na proklamiranim vrijednostima same Europske unije, a s druge strane na posuđenim idejama iz društvenoznanstvenih koncepata, primarno društvene integracije i društvene kohezije. Najvažnijim europskim dokumentima koji se tiču integracije migranata nedostaje ponajprije uvid u društvenu stvarnost migranata, ali i u specifičnosti populacija te društvenih okvira u koje bi se novi migranti, prema simplificiranim pretpostavkama postojećih dokumenata, trebali u konačnici u potpunosti uklopiti. Suvremeni društvenoznanstveni koncepti i istraživanja koja se bave pitanjima integracije migranata nude puno bolja objašnjenja društvenih procesa u kojima sudjeluju populacije imigracijskih zemalja, uključujući i ranije imigrantske populacije kao i nove imigrante i tražitelje azila. Stoga ukazivanje na adekvatnije pristupe i promišljanja te problematike može pridonijeti formuliranju pristupa koji je puno primjereniji društvenoj stvarnosti »prilagodbe« svih aktera u procesu useljavanja novih migrantskih skupina.

Naša je namjera prikazati najrelevantnije dokumente EU-a o integraciji migranata te na temelju postojećih društvenoznanstvenih rasprava, napose novijih socioloških koncepata i istraživanja društvenih procesa koji uključuju migrante, ponuditi relevantniji okvir za angažman institucija EU-a u tim 
procesima. Najprije ćemo prikazati dijelove europskih dokumenata koji razmatraju mjere integracije migranata i utvrditi vezu tih dokumenata s dijelovima društvenoznanstvenih teorija $\mathrm{i}$ istraživanja koja se bave integracijom migranata. Prikaz i analiza relevantnih javnopolitičkih dokumenata EU-a slijedi kronološku, ali i konceptualnu podjelu na dva »vala« dokumenata $\mathrm{u}$ kojima se integracija migranata formulira kao društveni i politički fenomen na europskoj razini i razrađuju mjere kojima isprva dominira građanska integracija migranata, dok se težište kasnije polako znatnije premješta na predmigracijske mjere integracije, društvenu koheziju, upravljanje raznolikostima i sigurnost. Nakon prikaza najvažnijih europskih dokumenata o integraciji migranata, analizirat ćemo dosadašnje kritike europske integracijske politike u društvenim znanostima. U posljednjem dijelu članka ukazat ćemo na relevantnost spoznaja suvremenih socioloških koncepata i istraživanja procesa integracije migranata za formuliranje pragmatičnog pristupa EU-a integraciji migranata.

Stoga su u fokusu ovoga rada politike integracije migranata, kao dio migrantskih politika EU-a. Prije prikaza, analize i kritike relevantnih europskih dokumenata, bitno je istaknuti neka ograničenja ovog rada. Rad ne analizira dokumente EU-a povezane s migracijskim politikama u širem smislu, niti s procesima europske integracije. Kontekstualizacija razvoja politika EU-a koje se bave integracijom migranata razmatranjem paralelnih procesa europske integracije, europeizacije te međuodnosa nacionalnog i nadnacionalnog u okviru pojedinoga nacionalnog konteksta, znatno nadilazi tematski fokus i prostorna ograničenja ovoga rada te je ostavljena kao potencijalna tema nekoga budućeg, po mogućnosti projektnoga, poduhvata.

\section{Integracija migranata u prvom "valu« dokumenata Europske unije}

Za razliku od migracijske politike EU-a koja se oslanja na zajedničke principe Unije (tzv. prvi stup), europske politike integracije migranata potpadaju pod »treći stup« (međuvladina razina), tj. nisu obvezujuće za države članice, premda se o njima odlučuje konsenzusom (Penninx i Garcés-Mascareñas, 2016: 167). ${ }^{1} \mathrm{Kad}$ bismo htjeli mapirati razvoj europske politike integracije

\footnotetext{
${ }^{1}$ Prema navedenim autorima, to ima dva učinka na formuliranje politika EU-a. Kao prvo, nacionalne vlade koriste svoje suvereno pravo na odlučivanje u mnogim područjima vezanim uz šire područje koncepta integracije te su zato politike integracije ograničene, "meke" politike. Kao drugo, nacionalne vlade mogu pokušavati prebaciti nacionalne politike integracije migranata na razinu EU-a.
} 
migranata, bilo bi bitno istaknuti da su segmenti integracije implicitno prisutni u starijim dokumentima. Primjerice, pravo na spajanje obitelji radnika migranata zajamčeno je Europskom socijalnom poveljom iz 1961., a kao prvi europski dokument o integraciji migranata najčešće se navodi Akcijski program Europske komisije u korist migrantskih radnika i njihovih obitelji iz 1974 (European Communities Commission, 1974). Unatoč tim starijim primjerima, potreba za zajedničkom migracijskom, a onda i integracijskom politikom, postaje izraženijom nakon sastanka Europskog vijeća u Tampereu 1999. Jedan od temeljnih dokumenata Europske komisije u kojem su podrobnije izloženi ciljevi i smjernice daljnjeg razvoja migracijskih i integracijskih politika, u skladu sa zaključcima iz Tamperea, jest Priopćenje o imigracijskoj politici prijašnje Europske zajednice (Commission of the European Communities, 2000). U tom se dokumentu znatan dio okvirnih smjernica odnosi na integraciju imigranata, uz uobičajene teme migracijskih politika kao što su upravljanje migracijskim tokovima, uključujući borbu protiv ilegalnih migracija, trgovanja i krijumčarenja ljudima, politike azila, dobrovoljnoga, ali i prisilnog povratka migranata.

Integracija je definirana kao »dvosmjeran proces koji uključuje prilagodbu i imigranta i društva primitka« (Commission of the European Communities, 2000: 19), a naglašava se i borba protiv diskriminacije, ksenofobije i rasizma, promoviranje raznolikosti, kao i načelna potreba osiguravanja jednakih prava imigrantima, državljanima trećih zemalja koji legalno borave u Europskoj uniji, uključujući i pravo na spajanje obitelji. Zagovara se stvaranje društva dobrodošlice (welcoming society), a EU se opisuje kao pluralističko društvo. Dokument sugerira i razvijanje koncepta građanskog državljanstva (civic citizenship) namijenjenog imigrantima. Stjecanje građanskog državljanstva nakon nekoliko godina predstavljalo bi "prvi korak u procesu stjecanja državljanstva države članice« (Commission of the European Communities, 2000: 19-20) te obuhvaćalo temeljna prava i obaveze. Iako dokument promovira integracijske politike kao sredstvo brze integracije, istovremeno se integracijskim mjerama nastoji obuhvatiti migrante druge generacije, s obzirom na to da je integracija dugotrajan proces (Commission of the European Communities, 2000: 20). U dokumentu se ističe i horizontalni pristup integraciji koji uključuje aktere iz civilnog društva, uz državne, regionalne i lokalne vlasti.

Spomenuti dokument iz 2000. pokazuje da od početka sustavnijeg promišljanja integracije migranata nakon okvirnih zaključaka iz Tamperea 
1999., unutar Europske komisije, ili barem među stručnjacima koji su pripremali prvi dokument na prijelazu u novo tisućljeće, postoji svijest o potrebi nadilaženja konceptualizacija integracije iz 20. stoljeća. To se ponajprije odnosi na nadilaženje koncepata asimilacije i integracije kao jednosmjernog procesa koji završava potpunom inkorporacijom. Početak formuliranja dokumenata EU-a koji se odnose na integraciju migranata karakterizira prepoznavanje integracije kao dvosmjernog procesa koji bi trebao uključivati pojedince, skupine i institucije društva primitka kao svjesne i aktivne aktere u tom procesu. Premda dokument Europske komisije iz 2000. ne uključuje objašnjenje procesa integracije, niti ima reference na sofisticiran, ali uglavnom napušten, pristup fazama integracije poput temeljnih socioloških radova koji se bave integracijom i asimilacijom imigranata u američko i europska društva u 20. stoljeću (npr., Gordon, 1964; Hoffmann-Nowotny, 1970; Esser, 1980), autori dokumenta prate trendove u društvenim znanostima koji naglašavaju višesmjernu adaptaciju i važnost okoline pojedinačnog i skupnog djelovanja imigranata. Taj dokument pokazuje vezu s promišljanjima integracije migranata koja propituju i kritiziraju ideju integracije u idealno zamišljena društva, normativno integrirana konsenzusom, a organizacijski državom (Joppke i Morawska, 2003). No, oni pritom prenaglašavaju važnost političke integracije i tzv. građanskog državljanstva, što će postati jasno u recentnim dokumentima EU-a.

U dokumentu se prepoznaju i prepreke integraciji migranata koje nisu vezane uz intrinzične, kulturne karakteristike imigranata, nego probleme koji proizlaze iz različitih oblika diskriminacije te specifično iz prepreka u diskursu i praksama u primajućem društvu, osobito iz ksenofobije i rasizma. Svi dokumenti koji su slijedili ove temeljne odrednice iz 2000. uglavnom su se zadržali na početnim principima, međutim utjecaj javnoga, političkog diskursa i društvenih procesa tijekom sljedećih petnaest godina snažno je utjecao na prilagodbu dokumenata koji se tiču integracije migranata. U dokumentima EU-a tako se sve više pokušavaju uklopiti zahtjevi za upravljanjem kulturnim raznolikostima kao posljedicom pojačane imigracije osoba različitog kulturnog podrijetla, a sekuritizacija migracija prodire i u integracijsku politiku.

Godine 2001. Komisija objavljuje prateći koordinacijski dokument o (zajedničkoj) imigracijskoj politici (Commission of the European Communities, 2001) kako bi se detaljnije razradili pojedini prijedlozi, njihova implementacija i usklađivanje. Dokument donosi smjernice u četiri područja: 
upravljanje migracijskim tokovima, prijam ekonomskih migranata, partnerstvo s trećim zemljama i integracija državljana tih zemalja. U skladu s multidimenzionalnosti fenomena migracija, zagovara se multidimenzionalnost migracijskih i integracijskih politika, a fokus dokumenta vezano uz integraciju migranata jest na ekonomskoj i društvenoj dimenziji (u tom se kontekstu pojam »integracije« koristi naizmjenično s »inkluzijom«).

Usprkos razumijevanju situacije u kojoj je nemoguće očekivati potpuno ravnomjerno integriranje migranata u sva područja društvenog života, dokumenti u sljedećim fazama razvoja migrantske politike i konkretnih mjera integracije migranata odaju prihvaćanje holističkog pristupa, što upućuje na to da relevantni politički akteri na europskoj razini ipak nisu zadovoljni ukupnim rezultatima integracije migranata u europska društva primitka pa počinju zagovarati cjelovit pristup integraciji.

Tako se u Priopćenju Europske komisije o imigraciji, integraciji i zapošljavanju iz 2003. (Commission of the European Communities, 2003) razmatra tadašnji zakonodavni okvir za integraciju državljana trećih zemalja u EU, uključujući i prioritete javnih politika na europskoj razini, s ciljem razvijanja učinkovitijih integracijskih politika. Imigracija bi trebala pomoći u odgovaranju demografskim i ekonomskim izazovima EU-a, a europski bi okvir za integraciju imigranata trebao biti koherentniji (Commission of the European Communities, 2003: 5). Stoga dokument zagovara holistički pristup integraciji, koju dijeli u šest područja (integracija u tržište rada, obrazovanje i jezične vještine, stanovanje, zdravlje i socijalne službe, društveni i kulturni okoliš, nacionalnost i građansko državljanstvo). S ciljem razvijanja uspješne holističke integracijske politike, dokument zagovara suradnju vlada kao glavnih aktera sa socijalnim partnerima, istraživačima, pružateljima javnih usluga, nevladinim sektorom i drugim akterima iz civilnog društva, uključujući imigrante (Commission of the European Communities, 2003: 4). Na kraju dokumenta navodi se definicija integracije kao »dvosmjernog procesa koji se temelji na uzajamnim pravima i pratećim obvezama državljana trećih zemalja koji zakonito borave [u Europskoj uniji] i društva primitka« i koji ovisi o vremenu boravka na način da dulji boravak podrazumijeva više prava i obveza (Commission of the European Communities, 2003: 7).

Zajednička temeljna načela za integracijsku politiku iz 2004. (Council of the European Union, 2004) predstavljaju sljedeći značajan pomak prema europskoj integracijskoj politici. Načela sadržajno obuhvaćaju različita 
područja integracije migranata, od zapošljavanja, pristupa obrazovanju i drugim institucijama, do društvene integracije putem »česte interakcije« s državljanima EU, a trebala bi predstavljati okvir za daljnju implementaciju i evaluaciju integracijskih politika. Iako je integracija definirana kao »dinamičan, dvosmjerni proces uzajamne prilagodbe svih imigranata i stanovnika država članica«, većina od jedanaest načela usmjerena je na imigrante kao svojevrsne objekte integracije od kojih se očekuju određena ponašanja. Iako bi državljani EU-a trebali biti ravnopravni partneri u procesu integracije, sadržajni fokus načela je na imigrantima, dok poticaj za »interakciju« koja je prepoznata kao ključna sastavnica integracije dolazi »odozgo«, a ne »odozdo«. Naposljetku, iako deklarativno podupiru sudjelovanje imigranata $\mathrm{u}$ demokratskom procesu i u formuliranju integracijskih politika i mjera, načela su primarno usmjerena na individualne imigrante i ne uključuju aktere poput migrantskih udruga (usp. i opširniju kritiku u Martiniello, 2006). ${ }^{2}$

Zajednička temeljna načela dalje su razvijena kroz smjernice i mjere u Zajedničkom programu za integraciju državljana trećih zemalja (Commission of the European Communities, 2005a). Programom se smjera »uspostaviti koherentan europski okvir za integraciju«, a nacionalni pristupi se nastoje uskladiti s onima na razini EU-a (Commission of the European Communities, 2005a: 4). U Zajedničkom programu su razrađena načela kroz smjernice za razvoj relevantnih politika na europskom i nacionalnom nivou, uz posebno poglavlje posvećeno zastupljenosti integracije u različitim područjima javnih politika i evaluacijskim mehanizmima (tj. načelima 10 i 11). Iako su Zajedničkim programom temeljna načela za integracijsku politiku prevedena u operabilniji oblik, dokument Europske komisije (2005a) ponavlja većinu pogrešaka Zajedničkih temeljnih načela: od pretvaranja migranata $\mathrm{u}$ objekte integracije, do pretpostavljene linearnosti i ireverzibilnosti procesa integracije te zanemarivanja mogućnosti segmentirane integracije. Unatoč tomu, u dokumentu se prepoznaju specifične potrebe migrantica, kao i dje-

\footnotetext{
${ }^{2}$ Godine 2004. objavljeno je i prvo izdanje Priručnika o integraciji (European Commission, 2004) namijenjeno tvorcima javnih politika i praktičarima u području integracije imigranata. Prvo je izdanje usmjereno na dva glavna područja - uvodne tečajeve za strance i građansko sudjelovanje, dok se ostala područja obrađuju u sljedećim izdanjima Priručni$k a$, onom posvećenom stanovanju i ekonomskoj integraciji (European Commission, 2007), onome o pristupu državljanstvu, obrazovanju mladih imigranata i ulozi medija u integraciji (European Commission, 2010) i drugo. Time su Zajednička temeljna načela (Council of the European Union, 2004) pretvorena u praktične smjernice za razvijanje i evaluaciju politika, a umjesto usvajanja jedinstvene definicije integracije, njezine se dimenzije tretiraju kao »korisna 'radna definicija'« (European Commission, 2004: 8).
} 
ce i mladih, a dio je mjera usmjeren na novopridošle migrante. Migrantske udruge navedene su kao jedan od važnih dionika »razvoja i implementacije integracijskih mjera«, iako se njihov utjecaj predviđa samo kao dio razrade temeljnog načela 9 (»sudjelovanje imigranata u demokratskom procesu i u formuliranju integracijskih politika i mjera«) u aneksu dokumenta (Commission of the European Communities, 2005a: 20).

Javnopolitički plan za zakonite migracije objavljen u prosincu 2005. (Commission of the European Communities, 2005b) također djelomično obuhvaća problematiku integracije migranata. Naglašava se važnost uvodnih programa za državljane trećih zemalja u obliku tečajeva jezika i kulture, tzv. građanskih orijentacijskih tečajeva i slično. Geografski se fokus integracijskih mjera proširuje kako bi obuhvatio i mjere započete u zemljama porijekla - uz tzv. predmigracijske integracijske mjere (pre-departure integration measures), osobito se naglašava važnost profesionalnih treninga i jezičnih tečajeva u zemljama porijekla. Migranti su još uvijek (jednosmjerno) u fokusu mjera kao glavni objekti integracije, a plan predviđa razvijanje dijela mjera prije sâme migracije, u suradnji s državama porijekla.

\section{Društvenoznanstvena kritika prvog "vala» dokumenata Eu- ropske unije o integraciji migranata}

Nakon prvog vala formuliranja i objavljivanja europskih dokumenata o integraciji migranata u europska društva, započele su i rasprave u društvenim znanostima o svrsishodnosti, primjenjivosti i utemeljenosti tih dokumenata. Osnovno pitanje koje je proizišlo iz tih rasprava tiče se mogućnosti formuliranja zajedničke politike integracije migranata na razini EU-a. Christian Joppke (2007) polazi od tvrdnje da se razlike u tretiranju integracije migranata među državama EU-a smanjuju suprotno ranijim pretpostavkama da će različiti modeli građanstva, političke pripadnosti i migrantskih politika u zemljama EU-a rezultirati i potpuno drukčijim pristupima integraciji imigranata. Politike integracije migranata u zemljama EU-a, prema Joppkeovu mišljenju, sve više konvergiraju, a nacionalne posebnosti pristupu integraciji smanjuju se do razine da se može dovesti u pitanje njihova svrhovitost (Joppke, 2007: 2). To je osobito vidljivo u području građanske integracije i uvođenju obveznih građanskih tečajeva i testova za imigrante nakon imigracije u Austriji, Danskoj, Finskoj, Njemačkoj, a u Nizozemskoj čak i prije imigracije. Tako je na kraju »multikulturalistička« Nizozemska uvela najrepresivniji model građanske integracije, građanska i »republikan- 
ska« Francuska prihvaća liberalistički pristup koji odustaje od asimilacije, a »segregacionistička« Njemačka prihvaća kanadsku varijantu građanske integracije s najmanje kontrole (Joppke, 2007: 19). Zajednička europska integracijska politika dobiva sve više na značaju, ne samo zato što se nacionalni modeli sve više približavaju, usprkos različitim polazišnim idejama o građanstvu i političkoj pripadnosti, nego i zato što se antidiskriminacijske mjere uspješnije formuliraju na europskoj razini, čak i kad se na kraju ne poštuju u potpunosti u zemljama članicama koje na njih u institucijama EU-a deklarativno pristaju.

Suprotno tome mišljenju, Jacobs i Rea (2007) tvrde da se nacionalni modeli integracije migranata još uvijek bitno razlikuju te da se tradicionalne klasifikacije modela integracijske politike mogu mijenjati, no znatne razlike u pristupu integraciji među zemljama članicama još uvijek opstaju. Čak se i regionalne i lokalne politike mogu bitno razlikovati unutar iste nacije-države, članice EU-a, pa se tako bitno razlikuju valonska i flamanska politika integracije migranata u Belgiji (Kaya, 2009) te amsterdamska i roterdamska u Nizozemskoj (Dekker i dr., 2015). Iz te perspektive smisao nadnacionalnoga europskog pristupa integraciji migranata pronalazi se upravo u pokušaju standardiziranja mjera integracije $i$ antidiskriminacijskih mjera koje će postupno približavati još uvijek filozofski, politički i praktično udaljene nacionalne, pa i regionalne, te lokalne modele integracije.

Opsežnu i vjerojatno najdublju kritiku europskih dokumenata koji se tiču integracije migranata, napose Zajedničkih temeljnih načela za integracijsku politiku (Council of the European Union, 2004) dao je Marco Martiniello već 2006. te proces formuliranja i donošenja tih dokumenata stavio u širi kontekst diversifikacije europskih društava koja sama produciraju raznolikost i nejednakost u svim segmentima, odnosno nejednaku integriranost samih europskih građana (Martiniello, 2006). Pritom, Martiniello ne prenaglašava značaj građanske integracije u ukupnom procesu integracije migranata u svim područjima društvene stvarnosti. Temeljna kritika europskih dokumenata koji se tiču integracije migranata polazi od činjenice da ni sami europski građani nisu podjednako integrirani u svoja društva, kao i od činjenice da se europska imigracijska politika ne može razvijati odvojeno od ukupne integracijske politike EU-a (Martiniello, 2006: 2). Ako se već inzistira na holističkoj politici integracije migranata onda je jasno da taj pristup mora uključiti razmatranje opće društvene integracije u europskim zemljama. 
Usprkos deklarativnom isticanju integracije migranata kao dvosmjernog procesa koji bi trebao uključivati i populacije i institucije društava primitka, kao i angažiranje institucija društava porijekla, integracija se $u$ temeljnim dokumentima EU-a ipak općenito promatra kao jednosmjeran i linearan proces, a posve se zanemaruje mogućnost prekida procesa integracije ili reverzibilnih momenata $u$ tom procesu. Treća generacija migranata ne mora nužno biti bolje integrirana od druge i prve (Martiniello, 2006: 6). U skladu s tim, nisu ni predviđene posebne mjere za migrante različitih generacija i različitih stupnjeva integriranosti u različite sfere imigracijskih društava. Oni se općenito tretiraju kao migranti iako im se legalni status, prava i obveze, kao i »stupanj integriranosti« u različitim sferama razlikuju. Dok su potomci useljenika uglavnom »integrirani na nižim društvenim razinama«, useljenici prve generacije još »uče kako novo društvo uopće funkcionira« (Martiniello, 2006: 7). Usto, imigranti se ne mogu tretirati kao jedinstvena skupina ili kao populacija jer su brojni imigranti dobro integrirani, a manje integrirani imigranti po različitim se parametrima zapravo ne razlikuju puno od slabije integriranih pripadnika većinske populacije. U skladu s tim, holistička integracijska politika treba uzeti u obzir sve koji su u različitim poljima više ili manje isključeni, a ne koncentrirati se samo na imigrante (Martiniello, 2006: 7). Konačno, politika integracije migranata u EU postavlja i kontradiktorne ciljeve jer s jedne strane očekuje da će imigranti $u$ procesu integracije $u$ potpunosti odbaciti svoje transnacionalne veze, ponajprije sa zemljom porijekla, a s druge se strane očekuje da će migranti pomoći u razvoju tih istih zemalja (Martiniello, 2006: 8).

Rasprava o europskoj integracijskoj politici migranata, međutim, nije imala velikog utjecaja na europske institucije koje se bave integracijskom politikom migranata. Umjesto fokusiranja na primjedbe i popravljanje uočenih nedostataka, posebno u primjeni holističke integracije, europske institucije počinju uvoditi nove kategorije i elemente integracije u svoje dokumente bez puno razmišljanja o provedivosti popisanih mjera po područjima.

\section{Integracija migranata u drugom "valu« dokumenata Europ- ske unije}

Poslije prvog »vala« donošenja dokumenata u kojem se integracija migranata formulira kao društveni i politički fenomen na europskoj razini i razrade mjera među kojima dominira građanska integracija migranata, a nakon razdoblja razmjene iskustava među državama članicama te višegodišnje 
stanke u donošenju dokumenata na razini EU-a, uslijedio je novi »val« usvajanja dokumenata $u$ kojima se težište polako premješta na predmigracijske mjere integracije, ali i koncepte poput društvene kohezije, upravljanja raznolikostima i sigurnosti. Prvi relevantan dokument za integraciju migranata na europskom nivou u sljedećoj fazi reglementiranja integracije jest Europski program za integraciju državljana trećih zemalja iz 2011. (European Commission, 2011a). ${ }^{3}$ U uvodu dokumenta učinkovita integracija migranata predstavljena je kao sredstvo izlaženja na kraj s raznolikim i multikulturnim društvima Europe i ostvarivanja koristi od migracija. Integracija je opisana kao »dinamičan, dugotrajan proces« koji uključuje više područja javnih politika na više razina (European Commission, 2011a: 3), a u dokumentu se identificiraju integracijski izazovi i donose preporuke za države članice i Europsku komisiju u trima glavnim područjima integracijskih mjera (sudjelovanje migranata u različitim sferama društvenog života, uključivanje lokalnih vlasti u proces integracije, ali i država porijekla migranata). Zakoniti su migranti istaknuti kao glavni fokus integracijskih mjera, s dodatnim naglaskom na migrantice, osobe pod međunarodnom zaštitom i Rome. Za razliku od prethodnih dokumenata, Europski program (European Commission, 2011a) više naglašava ulogu migrantskih organizacija i predstavnika te lokalnih vlasti u procesu integracije, zagovarajući pristup »odozdo prema gore« (bottom-up). Usto, u dokumentu se ponovno ističe uloga država porijekla u poticanju procesa integracije, kroz razvijanje i implementiranje predmigracijskih mjera, poticanje veza s dijasporom (osobito kroz promoviranje transnacionalnog poduzetništva, financijskih doznaka i transfera znanja i vještina) te stimuliranje privremenih i cirkularnih migracija. U završnom dijelu dokumenta (European Commission, 2011a: 11) prvi se put spominje pristup integraciji kao »trosmjernom procesu« koji uključuje migrante, države primitka, ali i države porijekla.

U pratećem dokumentu iz iste godine (European Commission, 2011b) navode se različite mjere na razini EU-a koje podržavaju proces integracije

\footnotetext{
${ }^{3}$ »Nakon donošenja Zajedničkog programa za integraciju državljana trećih zemalja 2005. društveni se kontekst u zemljama EU-a mijenja, a integracijske mjere iz Programa donesene 2005. ne polučuju željene rezultate. Kako bi došlo do usklađivanja integracijskih mjera s izmijenjenim društvenim prilikama u zemljama EU-a, donosi se novi program - Stockholmski (2009. - 2014.). Njime se integracijske politike želi uskladiti s drugim relevantnim područjima kao što su, primjerice, obrazovanje i tržište rada s ciljem postizanja što brže i efikasnije društvene uključenosti imigranata.« (Institut za migracije i narodnosti, 2016: 7-8).
} 
migranata, uključujući i primjere dobrih praksi. Integracija je definirana kao »multidimenzionalni proces interakcija između migranata i društva primitka« (European Commission, 2011b: 2), a pretpostavljeno inicijalno uniformno društvo primitka treba se »nositi s rastućom raznolikošću i novim kulturnim identitetima«. Stoga je integracija koncipirana kao nešto čime treba upravljati (managing), a »učinkovite integracijske politike zahtijevaju snažne akcije koje uključuju različita područja javnih politika i različite aktere na lokalnim, regionalnim i nacionalnim nivoima« (European Commission, 2011b: 3). U skladu s tim, u dokumentu su na više od 30 stranica navedeni i kratko opisani različiti programi i direktive iz područja migracija i integracije migranata, uključujući i dostupne financijske instrumente, statističke podatke i programe za znanstvena istraživanja.

Komunikacija Europske komisije Put ka ostvarenju otvorene i sigurne Europe (Europska komisija, 2014) također djelomično obuhvaća problematiku integracije migranata, unatoč naglasku na sigurnosnim aspektima migracija. Prepoznato je da »integracija i dalje predstavlja izazov« u Europi koja je predstavljena kao »raznoliko društvo« (Europska komisija, 2014: 4) kojem treba veća društvena kohezija kroz ekonomsku i društvenu integraciju migranata.

Deset godina nakon njihova donošenja, Vijeće EU-a potvrđuje Zajednička temeljna načela za integracijsku politiku (Council of the European Union, 2014) i njihovu ulogu u daljnjem razvoju integracijskih mjera i praksi država članica. Posebno je istaknuta integracija kao dugoročan i višeslojan proces koji zahtijeva holistički pristup, kao i potreba za daljnjim razvojem suradnje država porijekla i primitka te jačim uključivanjem aktera iz privatnog sektora (Council of the European Union, 2014).

Godine 2015. Europska komisija objavljuje Europski migracijski program (Europska komisija, 2015). Iako se ističe složenost fenomena migracija, naglasak je u dokumentu na mjerama za upravljanje i suzbijanje neregularnih migracijskih tokova u Sredozemlju. Integracija migranata obuhvaćena je uglavnom kroz razmatranje kratkoročnih i dugoročnih mjera za prihvat i razmještaj izbjeglica i tražitelja azila u EU, u skladu s načelom »poštenog i ravnomjernog sudjelovanja svih država članica« (Europska komisija, 2015: 4).

Jedan od recentnijih dokumenata je i Akcijski plan za integraciju državljana trećih zemalja iz lipnja 2016. (European Commission, 2016). Spomenuti dokument predstavlja zajednički okvir za daljnji razvoj nacionalnih 
integracijskih politika, uključujući i oblike podrške Europske komisije, s popisom konkretnih mjera čija se realizacija planira u dvogodišnjem razdoblju. Nastavljajući se na Europski program za integraciju državljana trećih zemalja iz 2011. (European Commission, 2011a), dokument izdvaja prioritetna područja integracijskih mjera: predmigracijske mjere (npr., učenje jezika i stručno osposobljavanje), obrazovanje, integraciju u tržište rada (s naglaskom na prepoznavanje kvalifikacija i osiguravanje stručne prakse državljanima trećih zemalja, uključujući izbjeglice) te pristup uslugama (npr., stanovanje za izbjeglice, zdravstvena zaštita). Među prioritetnim područjima također se nešto eksplicitnije zagovara aktivno sudjelovanje državljana trećih zemalja u kreiranju i implementaciji relevantnih integracijskih politika (European Commission, 2016: 12), kao i uloga sportskih klubova, kulturnih organizacija i udruga mladih kao svojevrsnih facilitatora društvene integracije. Dokument smjera pridonijeti razvoju EU-a kao »kohezivnog društva«, a dvosmjerni proces integracije je (re)definiran tako da uključuje pružanje »značajnih mogućnosti sudjelovanja u privredi i društvu« države primitka, a ne samo »očekivanje od državljana trećih zemalja da prihvate temeljne vrijednosti EU-a i nauče jezik domaćina« (European Commission, 2016: 5).

Kada se pogledaju teme i način obrađivanja problema u procesu integracije u dokumentima EU-a nakon 2011. uočljiv je sve jači utjecaj društvene i političke stvarnosti u najvećim europskim zemljama imigracije na ritam donošenja i sadržaj europskih dokumenata koji se tiču integracije migranata. Čini se da autori dokumenata EU-a uglavnom prate javni diskurs unutar tih zemalja i prenose temeljni ton javnih rasprava u dokumente, a institucije EU-a reagiraju na probleme tek kad se pojave te ne predviđaju trendove $\mathrm{u}$ procesu integracije. To je osobito vidljivo u sve većem inzistiranju na društvenoj koheziji i sigurnosti u procesu integracije koje su postale opća mjesta u javnom diskursu zemalja EU-a, ali i nacionalnim, institucionalnim pristupima integraciji migranata. No, dok su se u ranijim dokumentima autori jasnije referirali na društvenoznanstvene koncepte, reference na društvenu koheziju većim dijelom nisu usmjerene na koncept koji se razvija još od 19. stoljeća (Bruhn, 2009), nego se uglavnom odnose na javne i ideološke rasprave u kojima se društvena kohezija shvaća kao završno stanje integracije društvenih skupina. No, u društvenim znanostima koncept društvene kohezije nije popularan upravo zbog nemogućnosti jasnog definiranja i određivanja kako bi to stanje trebalo izgledati u stvarnosti, a znanstvenici koji se žele baviti pitanjem kohezije okreću se analizi 
društvenih mreža jer na taj način lakše mogu proučavati obrasce društvenih veza s obzirom na različite stupnjeve povezanosti u mrežama bez obzira na veličinu skupine (Bruhn, 2009: 47). Iako je moguće opisati društvenu koheziju, odnosno njezinu snagu, kroz varijacije u različitim područjima poput zajedničkih vrijednosti i civilne kulture, društvene kontrole, društvene solidarnosti, društvenih mreža i društvenog kapitala, vezanosti uz mjesto i identitet (Forrest i Kearns, 2001: 2129), istraživači uglavnom mjere društvenu koheziju samo kroz povjerenje i zajedničke društvene norme.

Europski dokumenti o integraciji migranata od 2011. sve više naglašavaju pitanje sigurnosti, a opća sekuritizacija tih dokumenata počinje s »izbjegličkom ili migrantskom krizom« i sve češćim terorističkim napadima u čija su planiranja i izvedbe bili uključeni imigranti muslimanske vjeroispovijesti ili njihovi potomci. Isto tako dokumenti EU-a prate opći trend sekuritizacije koji se dotad razvijao u zemljama članicama (Kaya, 2009). No, u migracijskim dokumentima EU-a u kojima sve češće dominira sekuritizacijski diskurs, previđa se činjenica da je značajan broj terorista druge generacije imigranata prema svim klasičnim parametrima bio dobro integriran te da su do svoje radikalizacije imali slične kulturne preferencije ostalim pripadnicima te generacije (usp. Roy, 2017). Umjesto specificiranja mjera za suzbijanje radikalizacije i regrutiranje terorista među drugom generacijom, dokumenti EU-a ostaju nedovoljno specifični i normativno vezani uz ideju da imigracija sama po sebi jest sigurnosni problem, a da proces integracije implicitno smanjuje sigurnosne rizike bez prethodno jasnih empirijskih dokaza.

\section{Od normativnog pristupa Europske unije integraciji migra- nata prema europskom integracijskom servisu utemeljenom na društvenoznanstvenim spoznajama?}

Normiranje i reglementiranje pristupa integraciji migranata na razini EU-a rezultiralo je skupom dokumenata koji još uvijek traže odgovore na pitanja koja su se pojavila već nakon prvog vala dokumenata do 2006. U sljedećim točkama sažimamo probleme općega, normativističkog pristupa integraciji migranata te rekapituliramo pitanja s obzirom na prethodno utvrđene probleme postavljanja jedinstvenoga europskog nadnacionalnog okvira za integraciju migranata:

1. Postoji nerazjašnjeno pitanje potrebe formuliranja integracijskog okvira na nadnacionalnoj razini. Temeljni principi političke pripadnosti, kao i 
filozofije integracije (Favell, 2001) u zemljama članicama EU-a još se uvijek bitno razlikuju (Jacobs i Rea, 2007), iako se nacionalne integracijske mjere pojedinih zemalja članica sve više približavaju (Joppke, 2007). Svi dokumenti institucija EU-a koji se tiču integracije migranata odaju dojam pokušaja standardiziranja principa integracije te pokušaja definiranja mjera koje bi poboljšale ishode tog procesa, a koje bi bile primjenjive u svim zemljama EU-a bez obzira na njihovu temeljnu filozofiju integracije. S jedne strane EU postavlja zajednički okvir i mjere »odozgo prema dolje«, a s druge posve ovisi o političkoj potpori političkih predstavnika zemalja s različitim filozofijama pripadnosti naciji i uključivanja »stranaca« u nacionalna društva.

2. Ukoliko je namjera autora brojnih europskih dokumenata, koji se tiču integracije imigranata, standardiziranje principa integracije za sve zemlje članice, postavlja se i pitanje potrebe specificiranja posebnih mjera integracije za sve zemlje članice u kojima postoje različiti integracijski problemi na lokalnoj, regionalnoj i nacionalnoj razini. Recentni dokumenti EU-a, poput Akcijskog plana za integraciju državljana trećih zemalja (European Commission, 2016), zamišljeni su kao zajednički okvir za daljnji razvoj nacionalnih integracijskih politika, koji pretpostavlja i podršku Europske komisije nacionalnim institucijama zemalja članica, s popisom konkretnih mjera čija se realizacija planira u dvogodišnjem razdoblju. No, još uvijek nije jasno kako će Europska komisija provjeravati ishode primijenjenih mjera te hoće li uopće biti u mogućnosti sankcionirati eventualno neprovođenje tih mjera.

3. Svrhovitost nadnacionalnog pristupa integraciji migranata upitna je i zato što europsko društvo ne postoji u obliku nacionalnog društva, nego ponajprije kao relacijsko polje međupovezanosti (Delanty, 2016). EU nije ni država, iako ima neke karakteristike federalne države. Iz perspektive sistemske teorije, EU je ponajprije konglomerat koji ne stvara supstancijalnu cjelinu, nego horizontalno povezuje široke oblike racionalnosti, a njezina politika pokušava smanjiti asimetrije funkcionalno diferenciranih segmenata društva (Kjaer, 2007). Ako je točno da EU ne pokušava biti nadređeni politički sistem drugim funkcionalnim sistemima (Kjaer, 2007: 369), onda ne može ni propisivati integracijske mjere »odozgo prema dolje«, nego samo predlagati smanjivanje asimetrije $u$ području integracije $i$ horizontalno poticati uključivanje migranata $\mathrm{u}$ različite društvene sisteme nevezano za nacionalne migrantske 
politike. Ni novi elementi političkog odlučivanja unutar Lisabonskog ugovora, ni glasovanje kvalificiranom većinom u Vijeću EU-a, ni veća uključenost Europskog parlamenta u zakonodavni proces kroz suodlučivanje s Vijećem EU-a, nisu promijenile činjenicu da politički sistem EU-a još uvijek uglavnom djeluje kao koordinator i arbitar između funkcionalno diferenciranih sistema (Kjaer, 2017). Njegova je supstancijalna zadaća i dalje djelovati kao »motor hiperkompleksne regulacije rizika« (Kjaer, 2017: 221), pa tako i rizika povezanih s neuspješnom integracijom migranata $\mathrm{u}$ različite društvene sisteme, a ne normiranje statičnih programa i mjera za nacionalno kompartmentalizirani prostor EU-a.

4. Uz pitanje potrebe formuliranja integracijskog okvira na nadnacionalnoj razini otvara se i pitanje integracije drugih građana zemalja EU-a koji se učestalo isključuju iz tržišta rada, političke participacije, sustava obrazovanja, zdravstva i tako dalje (Martiniello, 2006). „Društvena kohezija« ne može se postići odvajanjem mjera za migrantsku populaciju, pogotovo ako se uzme u obzir da se holistički pristup, koji se toliko zagovara $\mathrm{u}$ relevantnim dokumentima, konceptualno i praktično ne može primijeniti bez uključivanja svih populacija.

Nekritičko preuzimanje koncepata društvenih znanosti i dominantnog diskursa javnosti zemalja članica u dokumentima EU-a rezultiralo je serijom dokumenata koji odaju želju autorâ da s jedne strane standardiziraju pristup integraciji imigranata $\mathrm{u}$ EU te da s druge strane predlože mjere integracije koje se donekle temelje na indikatorima integracije koje razvijaju društveni znanstvenici (npr., Migrant Integration Policy Index /MIPEX/4). No, koncepti integracije i društvene kohezije problematični su u terminološkom i konceptualnom smislu i u samim društvenim znanostima, a često se čak i koriste kao sinonimi. Ne postoji ni šire slaganje među društvenim znanstvenicima o temeljnoj definiciji integracije društva i integracije imigranata u društvo, a kamoli konsenzus o integraciji kao konceptu koji bi se mogao nedvosmisleno koristiti u istraživanjima i objašnjenju najvažnijih suvremenih društvenih procesa. Uz integraciju, društvene znanosti, a sve češće i politički akteri, koriste se terminima poput asimilacije, apsorpcije, akulturacije, akomodacije, inkorporacije, inkluzije, participacije i tako dalje, a da se pritom u različitim kontekstima ti termini prikazuju i kao zasebni dijelovi integracijskog procesa. Čini se da politički, ali i društvenoznan-

\footnotetext{
${ }^{4}$ http://www.mipex.eu/.
} 
stveni diskurs, ostaje vezan uz metafore bez mogućnosti nedvosmislenog definiranja termina i koncepata.

Usprkos tomu, termin integracija gotovo uvijek upućuje na koncipiranje društva kao ograničene funkcionalne cjeline koju zapravo strukturira država koja je sposobna kreirati institucije i politike u tu svrhu (Favell, 2003). No, društvena stvarnost svih »objekata« integracije, kako migranata tako i većinske populacije, pokazuje da se funkcionalističko koncipiranje društva bitno razlikuje od iskustava svih društvenih aktera uključenih u interakcije nakon imigracije u kompleksnom urbanom kontekstu. Od 2007. sve veći broj društvenih znanstvenika proučava fenomen pod okvirnim nezgrapnim nazivom »nadraznolikost «, ${ }^{5}$ koji se najjednostavnije može opisati kao brzi rast razlika unutar i između migrantskih i etničkih skupina s obzirom na rod, generacijsku pripadnost, obrazovanje, prostorni raspored i tako dalje u kontekstu visoke kulturne i društvene raznolikosti u urbanim sredinama Europe i Sjedinjenih Američkih Država (Crul, 2016). Pojednostavljena funkcionalistička pretpostavka da se zasebne migrantske i etničke skupine holistički integriraju u kulturno homogena i jasno ograničena nacionalna društva u potpunosti je uzdrmana promjenama društvene stvarnosti. One zahtijevaju nov teorijski pristup koji će uzeti u obzir vrlo dinamičnu međuigru etničnosti, dobi, obrazovanja, roda i legalnog statusa s jedne strane i većinsko-manjinskih odnosa $\mathrm{i}$ integracije u velikim gradovima $\mathrm{s}$ druge (Crul, 2016: 58).

Zbog promjena uvjeta integracije različitih tipova migranata i migrantskih skupina, kao i činjenice da je fenomen integracije multidimenzionalan, nije moguće očekivati ukupnu inkorporaciju migranata kao pojedinaca i skupina, nego eventualno integraciju u posebnim društvenim sferama i učvršćivanje pozicija u ekonomskom sistemu. Dosadašnja istraživanja u Sjedinjenim Američkim Državama i Europi pokazuju da se društveni proces integracije odvija u uvjetima kad se migranti i migrantske skupine ne mogu ravnomjerno integrirati jer imaju različite mogućnosti pristupa ekonomskim, kulturnim, društvenim i političkim resursima (Portes i Zhou, 2005). Imigranti se više ne integriraju ravnomjerno kroz dominantnu kulturu imigracijskog društva i socioekonomske institucije, nego najčešće kroz etničke enklave (Vermeulen, 2010; Zhou, 2014) i to s posljedicama koje se

5 O »superdiversity« vidi u Vertovec (2007), Arnaut (2012) te Crul, Schneider i Lelie (2013). O kritici koncepta, njegovu odnosu prema intersekcionalnosti i pojmovima hiperdiversity te super-diversity vidi u Meissner i Vertovec (2015). 
opisuju kao »asimilacija prema dolje« (Vermeulen, 2010: 1215), kad cijeli proces često ne završava ulaskom u kulturnu i socioekonomsku maticu, nego ulaskom i višegeneracijskim boravkom u »potklasi«, na društvenim, pa i prostornim marginama.

$\mathrm{Uz} »$ nadraznolikost« te nejednaku individualnu i skupnu integraciju migranata u različitim poljima društvenih odnosa, ukupnu sliku procesa integracije dodatno kompliciraju efekti transnacionalnih veza migranata. Od devedesetih godina 20. stoljeća raširena je ideja da suvremeni oblici komunikacije i jeftin transport omogućuju snažne transnacionalne veze migranata, posebice $\mathrm{s}$ društvom porijekla, što ih dodatno sprečava da se u potpunosti uklope u društvene odnose i kulturu društva primitka. Europski dokumenti s jedne strane traže od imigranata postupni raskid veza $\mathrm{s}$ društvom porijekla, no s druge strane od njih traže da utječu na demokratizaciju i modernizaciju tih istih društava (npr., Commission of the European Communities, 2001; European Commission, 2011a). Istraživanja međuodnosa migrantskog »transnacionalizma $\mathrm{i}$ integracije, međutim, pokazuju puno kompleksnije obrasce pri čemu se oba fenomena mogu nadopunjavati, biti u sinergiji, ali i antagonističkom odnosu (Erdal i Oeppen, 2013). U nekim slučajevima sinergija transnacionalizma i integracije vidljiva je čak i u slučaju transnacionalnog aktivizma, a ne samo svakodnevnih transnacionalnih aktivnosti i veza unutar obitelji (Hammond, 2013), no u većini slučajeva imigranti ne prestaju biti i emigranti te su veze s društvom porijekla uvijek važan dio strategije adaptacije i sociokulturne integracije u društvu primitka (Erdal, 2013). Nacionalna perspektiva stoga nije dovoljna za razumijevanje procesa integracije migranata jer konceptualno isključuje izuzetno važne veze, odnose i lojalnosti koji snažno utječu na ishode cijelog procesa.

»Nadraznolikost«, segmentirana integracija i jačanje transnacionalnih veza migranata pokazuju da je pretpostavljeno holističko i linearno integriranje migrantskih populacija velikim dijelom u koliziji s društvenom stvarnosti višedimenzionalne prilagodbe migrantskih i nemigrantskih populacija etničkim, demografskim, ekonomskim, kulturnim i drugim promjenama u urbanom kontekstu. Umjesto standardiziranja mjera integracije za nacijedržave na nadnacionalnom nivou, ili eventualno uz takvo standardiziranje, EU može ponuditi puno pragmatičniji pristup tretiranja problema integracije. Jedna od mogućnosti jest i izravna pomoć institucija EU-a i njezinih stručnjaka u lokalitetima i zajednicama koje pokazuju visok stupanj prostorne, društvene i posebno etničke segregacije, socioekonomsku dete- 
rioraciju u produženim periodima, »asimilaciju prema dolje« i tako dalje. Standardizacija dokumenata integracije može biti od pomoći nacionalnim institucijama i njihovim politikama, no najvažniji su integracijski problemi na lokalnoj razini, a to zahtijeva konkretan angažman u specifičnim slučajevima koji su problematični s obzirom na broj neregistriranih migranata, prostornu, ekonomsku i društvenu segregaciju, nepostojeću društvenu pokretljivost preko generacija, društvenu i kulturnu izolaciju, visok intenzitet konflikata unutar i između etničkih skupina i tako dalje. Takav pristup dakako uključuje i isključene i/ili segregirane pojedince i skupine nemigrantskog porijekla. Brojni su gradovi u Europskoj uniji već odavno počeli razvijati lokalne integracijske politike, na početku bez pomoći nacionalnih institucija, a recentnije čak i protivno tim institucijama (Penninx i GarcésMascareñas, 2016: 164-166). EU je postala aktivan partner u provođenju integracijskih politika gradova promovirajući i financirajući mrežu gradova kao i financirajući istraživanja o lokalnim politikama (Penninx i GarcésMascareñas, 2016: 157). ${ }^{6}$

Međutim, takvo »višerazinsko upravljanje« može dovesti do sukoba nacionalnih i lokalnih institucija te postaviti Europsku komisiju, uz ostale institucije EU-a, na stranu lokalnih, gradskih uprava nasuprot vladama zemalja članica. Naime, lokalne integracijske politike i mjere često karakterizira znatno liberalniji i pragmatičniji pristup integraciji migranata, za razliku od ekskluzivnijih i ideološki obojenih nacionalnih modela (usp. Penninx i Garcés-Mascareñas, 2016; Scholten, Collett i Petrovic, 2017). Navedeno može dovesti do nepoželjnih procesa razdvajanja politika na lokalnoj i nacionalnoj razini (tzv. policy decoupling), uključujući manjak koordinacije među akterima na različitim nivoima te disparatne ciljeve i poruke (Scholten, Collett i Petrovic, 2017). Institucije EU-a bi jačanjem praktične pomoći u obliku servisa za rješavanje lokalnih problema u gradovima, ali i drugim sredinama sa značajnijim brojem migranata, mogle pokazati vlastima na nacionalnoj razini da su lokalna praktična rješenja temeljena na društvenoznanstvenom pristupu i istraživanjima od koristi i nacijama-državama.

${ }^{6}$ Iz mreže EUROCITIES izrasla je inicijativa Solidarity Cities, na inicijativu gradonačelnika Atene, a kao odgovor na tzv. »izbjegličku krizu«. Među glavnim ciljevima te mreže jesu razmjena znanja i iskustava o prijemu i integraciji izbjeglica, zagovaranje direktnog financiranja gradova, izgradnja kapaciteta, tehnička i financijska pomoć među gradovima (http://solidaritycities.eu). Za druge lokalne primjere integracijskih inicijativa i politika vidi Penninx i Garcés-Mascareñas (2016), a za kritiku distinktivne lokalne dimenzije integracije Dekker i dr., 2015. 
Transdisciplinarni timovi društvenih znanstvenika, praktičara, migranata, predstavnika lokalnih, nacionalnih i nadnacionalnih političkih institucija trebali bi moći »servisirati« svaku lokalnu zajednicu koju karakteriziraju ranije pobrojane značajke poput ekonomske i društvene segregacije, slabe društvene pokretljivosti, visoke razine konflikta i tako dalje. Servis bi se pritom ponajprije odnosio na praktične savjete i mjere koje se tiču svih dionika, ali i u čijem formuliranju sudjeluju svi dionici - od migrantske i nemigrantske populacije, preko predstavnika državnih institucija poput policije, socijalne službe i tako dalje do relevantnih političkih predstavnika na lokalnom, ali i regionalnom, odnosno nacionalnom nivou. Servis za lokalne zajednice i gradove mogla bi financirati EU na temelju dogovorenih kriterija odabira, a prema razvijenim indikatorima unutar istraživanja o položaju migranata, ali i stupnju rizika od sukoba i isključenja u različitim sredinama. OECD i Europska komisija (OECD \& European Union, 2015) već su objavili indikatore temeljene na proučavanju položaja na tržištu rada i općoj ekonomskoj slici migrantske populacije, a Radna skupina Partnerstva za uključivanje migranata i izbjeglica (Working group of the Partnership on Inclusion of Migrants and Refugees) koordinira usporedive indikatore urbane integracije.

Ovisno o pojedinom lokalnom kontekstu, tj. razini diversifikacije ciljane populacije integracijskih mjera, kao i kompleksnosti društvenih procesa integracije, mjere bi se mogle razvijati u smjeru generičkih politika usmjerenih na pojedino susjedstvo, grad ili čak nacionalnu populaciju, umjesto specifičnih mjera koje izdvajaju migrante, a zanemaruju druge segmente populacije i šire društvene probleme (usp. Scholten, Collett i Petrovic, 2017). Na taj bi način »nadraznolikost« kao skupina varijabli i kontekst (usp. Meissner, 2015) mogla pridonijeti deesencijalizaciji ustaljenih (ponajprije etničkih) kategorija, a potencijalno i boljem ukorjenjivanju i učinkovitosti integracijskih mjera i praksi, kako bi one odgovarale društvenoj stvarnosti osoba kojima bi trebale pomoći. Navedeno može imati praktične implikacije i za činjenicu da se europskim politikama integracije »tretiraju« isključivo državljani tzv. trećih zemalja, dok državljani članica EU-a koji borave u drugoj državi nisu zahvaćeni integracijskim mjerama kako ih definira EU, unatoč potencijalnim problemima s kojima se susreću na lokalnoj razini.

Naposljetku i ne manje važno, kako bi se poboljšala protočnost informacija i osigurala primjenjivost relevantnih društvenoznanstvenih spoznaja 
unutar znanstvenoistraživačkih projekata koji se bave aspektima migracijskih i postmigracijskih fenomena i procesa u državama EU-a, istraživači bi trebali formulirati preporuke za daljnji razvoj javnih politika na lokalnoj, regionalnoj, nacionalnoj i/ili nadnacionalnoj razini te osigurati da rezultati znanstvenih istraživanja budu dostupni svim dionicima procesa integracije u skraćenom i čitljivom obliku. S druge strane, institucije EU-a također trebaju osigurati veću vidljivost i dostupnost podataka o relevantnim dokumentima, inicijativama i praksama, ali i uzeti u obzir rezultate i zaključke istraživanja o migracijama i integraciji migranata unutar vlastitih istraživačkih programa poput programa »Towards forward-looking migration governance: addressing the challenges, assessing capacities and designing future strategies «, ${ }^{7}$ čiji je poziv zaključen u ožujku 2018., a koji je između ostalog posvećen razvoju indikatora upravljanja migracijama. ${ }^{8}$

U tom kontekstu uspostavljanje i razvijanje Europske internetske stranice o integraciji ${ }^{9}$ predstavlja koristan alat za veću dostupnost informacija o lokalnim i nacionalnim integracijskim inicijativama, kao i mjesto na kojem se mogu provjeriti i prikupiti relevantni dokumenti EU-a u nešto preglednijem izdanju. Stranica je primarno namijenjena tvorcima javnih politika te »praktičarima« integracijskih inicijativa i mjera, no može pomoći i društvenim znanstvenicima prilikom formuliranja nacrta istraživanja te detektiranja tema i slučajeva za istraživanje u pojedinom nacionalnom, regionalnom ili lokalnom kontekstu.

\section{Zaključak}

Nakon sastanka Europskog vijeća u Tampereu 1999., integracija migranata postaje temom europskih dokumenata u nastojanju razvoja principa zajedničke integracijske politike EU-a. Unatoč tomu što europske politike integracije migranata nisu obvezujuće za države članice, EU nastoji ponuditi osnovne smjernice i okvir za daljnji razvoj nacionalnih, ali i regionalnih i lokalnih javnih politika integracije migranata. Na prethodnim su stranicama prikazani i analizirani glavni dokumenti EU-a, kao i elementi društveno-

\footnotetext{
$7 \mathrm{http} / /$ ec.europa.eu/research/participants/portal/desktop/en/opportunities/h2020/topics/migration-02-2018.html.

${ }^{8}$ Indikatori bi trebali omogućiti procjenu načina na koji lokalne, nacionalne, regionalne i globalne norme utječu na rasprostranjivanje migracijskih politika na različitim razinama i u različitom vremenu. Također se potiče i analiza uloge i potencijala uspješnih lokalnih inicijativa.

${ }^{9}$ https://ec.europa.eu/migrant-integration/home.
} 
znanstvene kritike europske politike integracije migranata. Prikaz relevantnih europskih dokumenata slijedi kronološku logiku kako bi se mapirao razvoj temeljnih ideja i dionika u procesu integracije.

Poslije prvog vala formuliranja i objavljivanja europskih dokumenata o integraciji migranata u europska društva, započele su i rasprave u društvenim znanostima o svrsishodnosti, primjenjivosti i utemeljenosti tih dokumenata i mjera. Autori su, među ostalim, kritizirali pretpostavljenu jednosmjernost i linearnost procesa integracije, tretiranje migranata kao objekata integracije, ali i razmatrali značenje zajedničke europske integracijske politike s obzirom na nacionalne modele integracije migranata. Unatoč tim raspravama, i umjesto fokusiranja na popravljanje uočenih nedostataka, primjerice u primjeni holističke integracije, u drugom valu dokumenata EU-a nastavlja se nekritičko korištenje koncepata društvenih znanosti, kao i preuzimanje dijelova javnog diskursa o migracijama. Fokus dokumenata s građanske se integracije premješta na predmigracijske mjere integracije, društvenu koheziju, upravljanje raznolikostima i sigurnost. Na temelju analize najvažnijih europskih dokumenata koji se tiču integracije migranata moguće je zaključiti da im nedostaje uvid u društvenu stvarnost migranata, ali i u specifičnosti populacija te društvenih okvira u koje bi se novi migranti, prema pojednostavljenim pretpostavkama tih dokumenata, trebali $\mathrm{u}$ konačnici posve uklopiti.

Stoga je cilj ovoga rada bio razmotriti relevantne društvenoznanstvene rasprave te na temelju suvremenih socioloških koncepata i istraživanja migracijskih te postmigracijskih fenomena i procesa ponuditi elemente adekvatnijeg okvira za angažman europskih institucija u tim složenim procesima. Fenomeni (i društvenoznanstveni koncepti) »nadraznolikosti« segmentirane integracije i transnacionalnih veza migranata pokazuju da pretpostavljeno holističko integriranje migrantskih populacija nije u skladu s društvenom stvarnosti višedimenzionalne prilagodbe migrantskih i nemigrantskih populacija etničkim, demografskim, ekonomskim, kulturnim i drugim promjenama u urbanom kontekstu suvremenih europskih društava. Stoga umjesto standardiziranja mjera integracije za nacije-države na nadnacionalnom nivou, Europska unija valja ponuditi puno pragmatičniji pristup integraciji migranata utemeljen na relevantnim spoznajama društvenih znanosti, ali i konkretnim »terenskim iskustvima«.

Iako je nemoguće (a vjerojatno i nepoželjno) očekivati razvoj univerzalno primjenjivih mjera integracije migranata koje bi odgovarale svim 
kontekstima i slučajevima, istraživanje, pa onda i kreiranje javnih politika temeljenih na pozitivnim lokalnim iskustvima i njihovo prilagođeno premještanje $\mathrm{u}$ druge kontekste, može pridonijeti razvoju funkcionalnih europskih politika utemeljenih na aktualnim potrebama migrantskih populacija.

\section{LITERATURA}

Arnaut, Karel (2012). »Super-diversity: Elements of an Emerging Perspective«, Diversities, 14 (2): 1-16.

Bruhn, John (2009). The Group Effect: Social Cohesion and Health Outcomes. Boston: Springer.

Commission of the European Communities (2000). Communication from the Commission to the Council and the European Parliament on a Community Immigration Policy. Brussels: Commission of the European Communities. http:// eur-lex.europa.eu/legal-content/EN/TXT/PDF/?uri=CELEX:52000DC0757\&fro $\mathrm{m}=\mathrm{EN}$.

Commission of the European Communities (2001). Communication from the Commission to the Council and the European Parliament on an Open Method of Coordination for the Community Immigration Policy. Brussels: Commission of the European Communities. http://eur-lex.europa.eu/legal-content/EN/TXT/PD $\mathrm{F} /$ ?uri=CELEX:52001DC0387\& from $=\mathrm{pl}$.

Commission of the European Communities (2003). Communication from the Commission to the Council, the European Parliament, the European Economic and Social Committee and the Committee of the Regions on Immigration, Integration and Employment. Brussels: Commission of the European Communities. http://eur-lex.europa.eu/legal-content/EN/TXT/HTML/?uri=URISERV:c10611\& from $=\mathrm{EN}$.

Commission of the European Communities (2005a). Communication from the Commission to the Council, the European Parliament, the European Economic and Social Committee and the Committee of the Regions: A Common Agenda for Integration - Framework for the Integration of Third-Country Nationals in the European Union. Brussels: Commission of the European Communities. http://eur-lex.europa.eu/LexUriServ/LexUriServ.do?uri=COM:2005:0389:FIN:E $\mathrm{N}: \mathrm{PDF}$.

Commission of the European Communities (2005b). Communication from the Commission: The Policy Plan on Legal Migration. Brussels: Commission of the European Communities. http://eur-lex.europa.eu/legal-content/EN/TXT/PD $\mathrm{F} /$ ?uri $=$ CELEX:52005DC0669\&from=EN.

Council of the European Union (2004). The Common Basic Principles for Immigrant Integration Policy in the EU. Brussels: Council of the European Union. https://ec.europa.eu/migrant-integration/librarydoc/common-basic-principlesfor-immigrant-integration-policy-in-the-eu. 
Council of the European Union (2014). Council conclusions of the Council and the Representatives of the Governments of the Member States on the integration of third-country nationals legally residing in the EU. Brussels: Council of the European Union. https://www.consilium.europa.eu/media/28071/143109.pdf.

Crul, Maurice (2016). »Super-diversity vs. assimilation: How complex diversity in majority-minority cities challenges the assumptions of assimilation «, Journal of Ethnic and Migration Studies, 42 (1): 54-68. doi: 10.1080/1369183X.2015.1061425

Crul, Maurice, Schneider, Jens i Lelie, Frans (2013). Super-diversity. A New Perspective on Integration. Amsterdam: VU University Press.

Dekker, Rianne, Emilsson, Henrik, Krieger, Bernhard i Scholten, Peter (2015). »A Local Dimension of Integration Policies? A Comparative Study of Berlin, Malmö, and Rotterdam«, International Migration Review, 49 (3): 633-658. doi: 10.1111/imre. 12133

Delanty, Gerard (2016). »The making of European society: Contesting methodological nationalism«, Innovation: The European Journal of Social Science Research, 29 (1): 3-15. doi: 10.1080/13511610.2015.1051340

Erdal, Marta Bivand (2013). »Migrant Transnationalism and Multi-Layered Integration: Norwegian-Pakistani Migrants' Own Reflections«, Journal of Migration and Ethnic Studies, 39 (6): 983-999. doi: 10.1080/1369183X.2013.765665

Erdal, Marta Bivand i Oeppen, Ceri (2013). »Migrant Balancing Acts: Understanding the Interactions Between Integration and Transnationalism «, Journal of Migration and Ethnic Studies, 39 (6): 867-884. doi: 10.1080/1369183X.2013.765647

Esser, Hartmut (1980). Aspekte der Wanderungssoziologie. Assimmilation und Integration von Wanderern, ethnischen Gruppen und Minderheiten. Eine handlugstheoretische Analyse. Darmstadt: Luchterhand.

European Commission (2004). Handbook on Integration for Policy-makers and Practicioners (1st Edition). Brussels: European Commission. https://ec.europa. eu/migrant-integration/librarydoc/handbook-on-integration-for-policy-makersand-practitioners-1st-edition---2004.

European Commission (2007). Handbook on Integration for Policy-makers and Practicioners (2nd Edition). Brussels: European Commission. https://ec.europa. eu/migrant-integration/librarydoc/handbook-on-integration-for-policy-makersand-practitioners-2nd-edition.

European Commission (2010). Handbook on Integration for Policy-makers and Practicioners (3rd Edition). Brussels: European Commission. https://ec.europa. eu/migrant-integration/librarydoc/handbook-on-integration-for-policy-makersand-practitioners-3rd-edition---2010.

European Commission (2011a). Communication from the Commission to the Council, the European Parliament, the European Economic and Social Committee and the Committee of the Regions on European Agenda for the Integration of Third-Country Nationals. Brussels: European Commission. https://eur-lex. europa.eu/legal-content/en/ALL/?uri=CELEX:52011DC0455.

European Commission (2011b). European Union Initiatives Supporting the Integration of Third-Country Nationals. Brussels: European Commission. http:// eur-lex.europa.eu/legal-content/EN/TXT/PDF/?uri=CELEX:52011SC0957\&fro $\mathrm{m}=\mathrm{EN}$. 
European Commission (2016). Communication from the Commission to the Council, the European Parliament, the European Economic and Social Committee and the Committee of the Regions: Action Plan on the integration of third country nationals. Brussels: European Commission. http://ec.europa.eu/ dgs/home-affairs/what-we-do/policies/european-agenda-migration/proposalimplementation-package/docs/20160607/communication_action_plan_integration_third-country_nationals_en.pdf.

European Communities Commission (1974). Action Programme in Favour of Migrant Workers and their Families. Brussels: European Communities Commission. http://aei.pitt.edu/1278/1/action_migrant_workers_COM_74_2250.pdf.

Europska komisija (2014). Put ka ostvarenju otvorene i sigurne Europe. Brussels: European Commission. http://eur-lex.europa.eu/legal-content/HR/TXT/?uri= CELEX:52014DC0154.

Europska komisija (2015). Europski migracijski program. Brussels: European Commission. https://ec.europa.eu/home-affairs/sites/homeaffairs/files/what-we$\mathrm{do} /$ policies/european-agenda-migration/background-information/docs/communication_on_the european_agenda_on_migration_hr.pdf.

Favell, Adrian (2001). Philosophies of Integration: $\overline{I m m i g r a t i o n}$ and the Idea of Citizenship in France and Britain. Basingstoke: Palgrave.

Favell, Adrian (2003). »Integration Nations: The Nation-State and Research on Immigrants in Western Europe«, u: Grete Brochmann (ur.). Multicultural Challenge. Bingley: Emerald, str. 13-42.

Forrest, Ray i Kearns, Ade (2001). »Social Cohesion, Social Capital and the Neighbourhood«, Urban Studies, 38 (12): 2125-2143.

Gordon, Milton (1964). Assimilation in American Life: The Role of Race, Religion and National Origin. New York: Oxford University Press.

Hammond, Laura (2013). »Somali Transnational Activism and Integration in the UK: Mutually Supporting Strategies«, Journal of Ethnic and Migration Studies, 39 (6): 1001-1017. doi: 10.1080/1369183X.2013.765666

Hoffmann-Nowotny, Hans-Joachim (1970). Migration. Ein Beitrag zu einer soziologischen Erklärung. Stuttgart: Enke.

Institut za migracije i narodnosti (2016). Integracija migranata u Europskoj uniji s osvrtom na Hrvatsku: strateška polazišta Instituta za migracije i narodnosti. Zagreb: Institut za migracije i narodnosti. http://www.imin.hr/c/document_library/get_file?uuid=8aa80cd9-f191-4f01-b4cb-a302b8d14a0d\&groupId=1015 $\overline{6}$.

Jacobs, Dirk i Rea, Andrea (2007). »The end of national models? Integration courses and citizenship trajectories in Europe«, International Journal on Multicultural Societies, 9 (2): 264-283.

Joppke, Christian (2007). »Beyond National Models: Civic Integration Policies for Immigrants in Western Europe«, West European Politics, 30 (1): 1-22. doi: 10.1080/01402380601019613

Joppke, Christian i Morawska, Ewa (2003). »Integrating Immigrants in Liberal Nation-States: Policies and Practices«, u: Christian Joppke i Ewa Morawska (ur.). Toward Assimilation and Citizenship: Immigrants in Liberal Nation-States. New York: Palgrave Macmillan, str. 1-36. 
Kaya, Ayhan (2009). Islam, Migration and Integration: The Age of Securitization. New York: Palgrave Macmillan.

Kjaer, Poul F. (2007). »The Societial Function of European Integration in the Context of World Society«, Soziale Systeme, 13 (1-2): 369-380.

Kjaer, Poul F. (2017). »The EU's Model of Regional Integration in a Functionally Differentiated World Society«, u: Andreas Grimmel (ur.). The Crisis of the European Union: Challenges, Analyses, Solutions. Abingdon: Routledge, str. 215-225.

Martiniello, Marco (2006). Towards a coherent approach to immigrant integration policy(ies) in the European Union. Liège: Université de Liège.

Meissner, Fran (2015). »Migration in migration-related diversity? The nexus between superdiversity and migration studies«, Ethnic and Racial Studies, 38 (4): 556-567. doi: 10.1080/01419870.2015.970209

Meissner, Fran i Vertovec, Steven (2015). »Comparing super-diversity«, Ethnic and Racial Studies, 38 (4): 541-555. doi: 10.1080/01419870.2015.980295

OECD \& European Union (2015). Indicators of Immigrant Integration 2015: Settling In, Paris: OECD Publishing. doi: 10.1787/9789264234024-en

Penninx, Rinus i Garcés-Mascareñas, Blanca (2016). »Integration Policies of European Cities in Comparative Perspective: Structural Convergence and Substantial Differentiation«, Migracijske i etničke teme, 32 (2): 155-189. doi: 10.11567/ met.32.2.1

Portes, Alejandro i Zhou, Min (2005). »The new second generation: Segmented assimilation and its variants«, u: Carola Suarez-Orozco, Marcelo Suarez-Orozco i Desiree Baolian Qin-Hilliar (ur.). The New Immigration: An Interdisciplinary Reader. New York: Routledge, str. 85-104.

Roy, Olivier (2017). Jihad and Death: The Global Appeal of Islamic State. London: Hurst.

Scholten, Peter, Collett, Elizabeth i Petrovic, Milica (2017). »Mainstreaming migrant integration? A critical analysis of a new trend in integration governance«, International Review of Administrative Sciences, 83 (2): 283-302. doi: 10.1177/0020852315612902

Vermeulen, Hans (2010). »Segmented assimilation and cross-national comparative research on the integration of immigrants and their children «, Ethnic and Racial Studies, 33 (7): 1214-1230. doi: 10.1080/01419871003615306

Vertovec, Steven (2007). »Super-diversity and its implications«, Ethnic and Racial Studies, 30 (6): 1024-1054. doi: 10.1080/01419870701599465

Zhou, Min (2014). »Segmented assimilation and socio-economic integration of Chinese immigrant children in the USA«, Ethnic and Racial Studies, 37 (7): 1172-1183. doi: 10.1080/01419870.2014.874566 


\title{
European Migrant Integration Policy: From Standardising Measures for European Union Countries to Integration Service Based on Social Scientific Knowledge
}

\author{
Saša BOŽıć \\ Department of Sociology, University of Zadar, Croatia \\ sbozic@unizd.hr \\ Simona Kuti \\ Institute for Migration and Ethnic Studies, Zagreb, Croatia \\ simona.kuti@imin.hr
}

\begin{abstract}
The article presents and analyses the core European Union documents on migrant integration. On the basis of existing discussions within the social sciences, in particular more recent sociological concepts and studies of social processes involving migrants, the article aims to provide a more relevant framework for the European Union institutions' engagement in these processes. The authors analyse the criticism of European migrant integration policy stemming from social sciences and indicate the relevance of contemporary sociological concepts and research on the process of migrant integration for formulating a more pragmatic approach of the European Union to migrant integration. "Superdiversity", segmented integration and strengthening of transnational ties of migrants show that a holistic integration of migrant populations collides with the social reality of multidimensional adaptation of migrant and non-migrant populations to ethnic, demographic, economic, cultural and other changes in the urban context of contemporary European societies. The authors concluded that, instead of standardising integration measures for nation-states at a supranational level, the European Union should offer a more pragmatic approach to migrant integration based on relevant insights from social sciences as well as concrete "field experience" of researchers, practitioners, migrant organisations and local authorities.
\end{abstract}

Key words: migrant integration, European Union, public policies, migration, migrant policies, "superdiversity" 